\title{
MEMPERBAIKI TEGANGAN DAN RUGI-RUGI DAYA PADA SISTEM TRANSMISI DENGAN OPTIMASI PENEMPATAN KAPASITOR MENGGUNAKAN ALGORITMA GENETIKA
}

\author{
Syukri Yunus*, Heru Dibyo Laksono dan Putri Nidia \\ Jurusan Teknik Elektro, Fakultas Teknik, Universitas Andalas \\ *Corresponding author, e-mail: syukri_yunus@ft.unand.ac.id
}

\begin{abstract}
Abstrak - Suatu sistem tenaga listrik dikatakan memiliki tingkat keandalan yang tinggi apabila sistem tersebut mampu menyediakan pasokan energi listrik yang dibutuhkan oleh konsumen secara kontinyu. Rugi-rugi daya yang terjadi pada saluran mengakibatkan turunnya tegangan pada saluran dan menyebabkan kerugian karena semakin berkurangnya keandalan sistem dalam menyalurkan listrik ke beban. Untuk mengurangi terjadinya rugi-rugi daya pada saluran dilakukan pemasangan kapasitor. Pemasangan kapasitor dilakukan dengan memperhitungkan posisi penempatan serta ukurannya, agar penempatan kapasitor yang dilakukan dapat optimal dalam mengurangi rugi-rugi yang terjadi. Metode optimasi yang yang cukup efektif adalah algoritma genetika. Pada metode ini, penempatan kapasitor dilakukan dengan mengarah pada pemilihan kromosom yang diperoleh. Hasilnya akan diperoleh kromosom terbaik dari sebuah populasi yang ada yang berisi kondisi optimum penempatan kapasitor yang dapat memperkecil rugi-rugi daya yang terjadi pada saluran sekaligus meminimalisir banyaknya penggunaan kapasitor. Perbandingan yang bisa dilakukan dengan menggunakan aliran daya Newton-Raphson antara sebelum dan sesudah penempatan kapasitor.

Kata Kunci : Rugi-rugi daya, Tegangan, Algoritma genetika, Kapasitor, Kromosom.
\end{abstract}

\begin{abstract}
Electric power system is said to have a high degree of reliability if the system is able to provide a supply of electrical energy required by consumers continuously. Power loss that occurs in line resulting voltage drop on the line and cause a loss due to the decreasing reliability of the system to supply power to the load. To reduce the power loss in the line do installation of capacitors. Installation of capacitors conducted by calculating the position of the placement and size, so that placement of capacitors that do can be optimized to reduce losses that occur. Optimal methods are quite effective is algorithm genetics. In this method, capacitor placement is done with the chromosome leads to the selection obtained. The best results will be obtained from a chromosome that contains a condition that there is optimum placement of capacitors that can minimize power loss that occurs in the channel as well as minimize the amount of use of the capacitor. The comparison can be done by using Newton Raphson power flow between before and after forging capacitor.
\end{abstract}

Keywords : Power losses, voltage, algorithm genetics, capacitors, chromosome

\section{PENDAhUluAN}

Saat ini penggunaan tenaga listrik telah menjadi kebutuhan yang sangat penting bagi manusia. Kebutuhan akan tenaga listrik semakin meningkat baik itu untuk daerah perkotaan maupun untuk daerah pedesaan. Kondisi ini menyebabkan adanya pendistribusian energi listrik ke daerah-daerah tersebut.

Suatu sistem tenaga listrik dikatakan memiliki tingkat keandalan yang tinggi apabila sistem tersebut mampu menyediakan pasokan energi listrik yang dibutuhkan oleh konsumen secara kontinyu. Ada beberapa persoalan yang dihadapi oleh suatu sistem tenaga listrik untuk dapat mensuplai energi listrik secara kontinyu. Salah satunya adalah yang terkait dengan masalah kualitas daya listrik. Karena pusat beban pada umumnya terdapat pada lokasi yang jauh dari pusat pembangkitan tenaga listrik maka dibutuhkan penyaluran daya listrik untuk sampai ke konsumen. Dimana kualitas tegangan dan faktor daya sistem diusahakan tetap berada pada level yang telah ditentukan, untuk menjaga keandalan dari aliran daya tetap stabil dan dapat bekerja dengan baik.

Pertumbuhan beban diikuti dengan peningkatan permintaan suplai daya reaktif akibat beban yang bersifat induktif meningkat. Jika suatu jaringan tidak memiliki sumber daya reaktif di daerah sekitar beban maka semua kebutuhan beban reaktifnya dipikul oleh generator sehingga akan mengalir arus reaktif pada jaringan yang mengakibatkan faktor daya 
akan menurun, jatuh tegangan, dan rugi-rugi daya akan besar. Salah satu cara untuk memperbaiki tegangan dan mengurangi rugirugi daya adalah dengan menempatkan suatu kapasitor yang mempunyai nilai optimal pada lokasi yang optimal pula pada sistem transmisi. Penggunaan kapasitor ini mencakup masalah penentuan ukuran dan penempatan.

Kapasitor dipasang di lokasi strategis dan tepat untuk mengurangi rugi-rugi daya dan memperbaiki tegangan dalam batas yang diijinkan sehingga diperoleh kondisi kualitas aliran daya yang baik. Metode optimasi kapasitor yang digunakan pada penelitian ini adalah metode algoritma genetika dengan menggunakan software MATLAB. Algoritma genetika adalah salah satu teknik komputasi yang sesuai dengan ruang solusi yang sangat besar[1].

Parameter-parameter yang digunakan untuk fungsi objektif pada algoritma genetika adalah biaya pembelian kapasitor, biaya pemasangan kapasitor, biaya operasi dan pemeliharaan kapasitor serta biaya rugi-rugi daya pada sistem transmisi. Dengan meminimumkan parameterparameter tersebut maka akan didapatkan biaya minimum dalam penempatan nilai kapasitor yang optimal dan memenuhi batas-batas tegangan yang ditentukan[2].

Pada penelitian in permasalahan yang akan diselesaikan adalah menentukan lokasi dan nilai optimal kapasitor pada sistem transmisi Network Sumatera Barat dengan menggunakan metode algoritma genetika dan disimulasikan dengan software MATLAB. Dimana Studi aliran daya yang digunakan adalah metoda NewtonRaphson.

\section{TINJAUAN PUSTAKA}

\subsection{Kualitas Daya}

Kualitas daya adalah tingkat berpengaruhnya pembangkitan dan pengiriman daya listrik terhadap unjuk kerja peralatan listrik. Kualitas daya listrik juga dapat didefinisikan sebagai tingkat penyimpangan nilai nominal besarnya tegangan dan frekuensi. Permasalahan yang mempengaruhi kualitas daya yaitu aliran beban, hubung singkat, stabilitas aliran dan pengamanan atau proteksi[3].

\subsection{Studi Aliran Daya}

Masalah aliran daya mencakup perhitungan aliran dan tegangan sistem pada terminal tertentu atau bus tertentu. Representasi fasa tunggal selalu dilakukan karena sistem dianggap seimbang. Dalam setiap bus selalu terdapat empat besaran yaitu daya aktif, daya reaktif, magnitude tegangan dan sudut fasa. dalam studi aliran daya terdapat tiga tipe bus, dalam masingmasing tipe bus minimal diketahui dua dari empat besaran yang ada. Pada setiap perhitungan harus dipilih salah satu bus sebagai slack bus. Hubungan antar bus oleh jaringan dijelaskan dengan memakai nomor bus. Kondisi kerja harus selalu ditentukan untuk setiap studi[3].

\subsection{Aliran Daya dengan Metode Newton Raphson \\ Metode Newton Raphson lebih cepat} mencapai nilai konvergen sehingga proses iterasi yang berlangsung lebih sedikit tetapi setiap iterasinya memerlukan waktu yang relatif lebih lama, karena jumlah iterasinya sedikit, secara keseluruhan memerlukan waktu yang lebih singkat dalam penyelesaian aliran daya. Dasar dari metode Newton Raphson dalam penyelesaian aliran daya adalah deret taylor untuk suatu fungsi dengan dua variable lebih. Metode Newton Rhapson menyelesaikan masalah aliran daya dengan menggunakan suatu set persamaan non linier untuk menghitung besarnya tegangan dan sudut fasa tegangan tiap bus. Secara umum prosedur penyelesaian aliran daya dapat dilihat pada diagram alir Gambar 1.

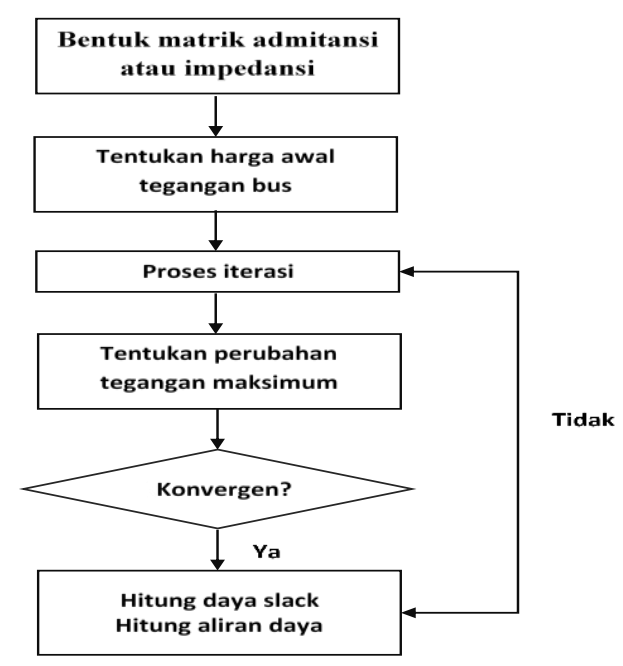

Gambar 1. Diagram Alir Perhitungan Aliran Daya[4]. 


\subsection{Algoritma Genetika}

Algoritma genetik merupakan metode yang sangat baik untuk penyelesaian masalah optimasi. Metode ini meniru kejadian yang ada di alam, tepatnya kejadian perolehan sesuatu yang terbaik melalui proses yang terjadi pada evolusi makhluk hidup[5] Algoritma genetik terdiri dari beberapa komponen sebagai berikut:

1. Populasi kromosom, merupakan kumpulan dari beberapa kromosom. Pada studi ini, kromosom terdiri dari kombinasi antara letak kapasitor dan ukuran kapasitor.

2. Evaluasi, untuk mendapatkan nilai yang disebut nilai fitnesss dari suatu kromosom. Nilai fitness menunjukkan tingkat kemampuan bertahan hidup kromosom. Nilai fitness yang digunakan dalam studi ini adalah nilai rugi-rugi daya saluran yang diperoleh dari metoda newton raphson.

3. Linear fitness rangking, yaitu penskalaan dan pengurutan nilai fitness dari yang terbesar hingga yang terkecil

4. Elitisme, untuk menjaga agar kromosom yang terpilih tidak rusak maka perlu dibuat kopinya dan disimpan.

5. Seleksi roda roulette, untuk memilih kromosom yang menjadi induk dalam pindah silang

6. Pindah silang, mengkombinasikan 2 buah kromosom

7. Mutasi adalah proses pengubahan komposisi yang terdapat didalam kromosom untuk memperoleh hasil keturunan yang lebih baik.

8. Populasi baru, akan membentuk generasi baru dan siap di evaluasi kembali.

Parameter-parameter algoritma genetika[6] :

1. Ukuran populasi (pop_size)

Jumlah individu yang terdapat didalam suatu populasi yang merupakan kromosom atau starting. Ukuran populasi yang sering digunakan berkisar antara $50-80$.

2. Jumlah generasi (Max-Gen)

Semakin besar jumlah generasi maka semakin optimum solusi yang mungkin dicapai..

3. Probabilitas crossover $(P c)$

Rasio dari Offspiring yang dihasilkan dalam setiap generasi di dalam suatu populasi. Jika $P c$ semakin besar maka semakin cepat struktur kromosom baru terbentuk dalam populasi, begitu pula sebaliknya.

4. Probabilitas mutasi $(\mathrm{Pm})$
Persentase dari jumlah total gen yang akan mengalami mutasi. Jika $\mathrm{Pm}$ terlalu rendah akan mengakibatkan gen yang berpotensi tidak dapat dimutasikan, begitu pula sebaliknya[7].

\section{METODOLOGI}

\subsection{Penentuan Penempatan Kapasitor Pada Sistem Tenaga Listrik}

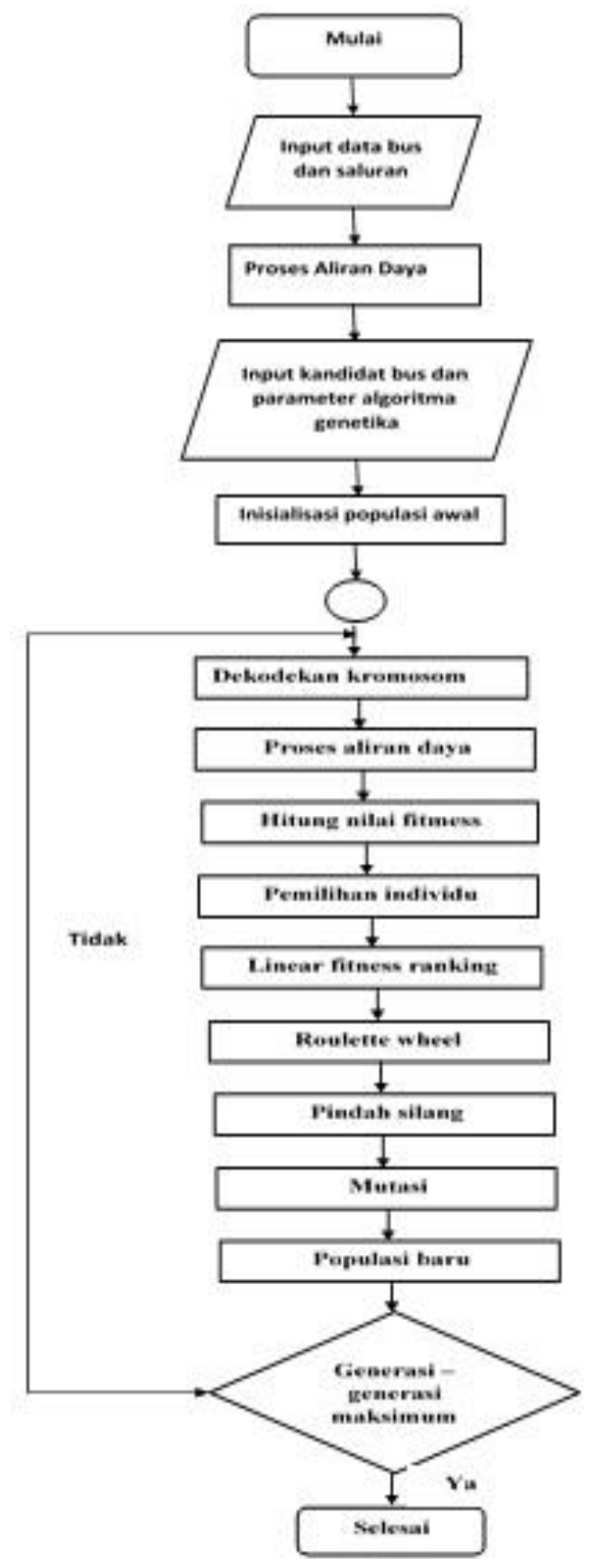

Gambar 2. Flow Chart Penelitian 
Proses pertama yang dilakukan adalah menghitung besar rugi-rugi daya pada saluran sebelum pemasangan kapasitor menggunakan metode Newton-Raphson berdasarkan data-data pembangkitan menggunakan program Matlab. Setelah analisa aliran daya dilakukan diperoleh rugi-rugi yang terjadi, kemudian berikutnya menentukan titik-titik dan besarnya nilai kapasitor yang akan digunakan dengan metode algoritma genetik. Dari metode algoritma genetika ini akan terlihat perubahan nilai-nilai pada aliran daya yang terjadi, terutama pada nilai rugi-rugi yang dihasilkan, sehingga dapat diketahui berapa nilai kapasitor yang akan dipasang dan dimana posisi penempatan kapasitor pada sistem tenaga listrik. Tahapan penelitian sesuai pada gambar 3.1 berikut.

\subsection{Studi Aliran Daya dengan Menggunakan Metode Newton Raphson}

Penelitian ini menggunakan data pembangkitan, beban dan saluran dari sistem tenaga listrik di Sumatera Barat yang terdiri dari 20 bus. Dari analisa aliran daya ini akan terlihat nilai rugi-rugi daya yang terjadi pada saluran. Ada 2 tahap yang dilakukan. Tahap pertama dilakukan analisa tanpa pemasangan kapasitor sebagai kompensasi. Tahap kedua dilakukan dengan pemasangan kapasitor pada titik atau bus-bus yang telah ditentukan sebelumnya. Lalu hasil yang diperoleh tadi dibandingkan untuk melihat perbedaan rugi-rugi yang terjadi.

\subsection{Penentuan Penempatan Kapasitor dengan Menggunakan Algoritma Genetik}

Pada penggunaan algoritma genetik untuk penempatan kapasitor, kemungkinan terjadinya kawin silang dan mutasi merupakan faktor penting. Kawin silang diterapkan pada seluruh populasi dan efek pencarian hingga mencapai maksimum. Biasanya peluang kawin silang bernilai antara 0,7 sampai 1,0. Bahkan ada juga yang menetapkan nilai kawin silang antara 0,6 sampai 0,9 [8]. Operator mutasi menjaga penyebaran dalam populasi dengan probabilitas yang kecil. Pada umumnya hanya ada satu mutasi pada setiap string atau gen. Nilainya pun sangat kecil, sekitar 1 dibagi dengan jumlah gen. Penempatan kapasitor ini dilakukan dengan langkah - langkah sebagai berikut :

1. Menetapkan nilai awal dan nilai parameter metode (jumlah kromosom, jumlah gen, nilai
$P_{\text {cross }}$ dan $P_{m u t}$. Pada penelitian ini dilakukan pemvariasian nilai-nilai parameter yang akan digunakan untuk melihat bagaimana pengaruh algoritma genetika untuk kondisi parameter yang berbeda. Tabel dibawah ini merupakan nilai yang digunakan dalam penelitian ini.

\begin{tabular}{|c|c|} 
Tabel 1. Nilai & $P_{\text {cross dan }} P_{\text {mut }}$ \\
\hline$P_{\text {cross }}$ & $P_{\text {mut }}$ \\
\hline $\mathbf{0 , 7}$ & $\mathbf{0 , 0 2}$ \\
\hline $\mathbf{0 , 8}$ & $\mathbf{0 , 0 3 5}$ \\
\hline $\mathbf{0 , 9}$ & $\mathbf{0 , 0 5}$ \\
\hline $\mathbf{1}$ & $\mathbf{0 , 5}$ \\
\hline
\end{tabular}

2. Jumlah gen merupakan jumlah bus yang dipakai pada sistem tenaga listrik.

3. Membandingkan untuk menentukan kromosom terbaik yang dihasilkan dari tiap percobaan.

4. Pemilihan kromosom yang akan digunakan sebagai parameter optimasi.

5. Setelah kromosom yang terbaik diperoleh, selanjutnya membandingkan hasil aliran daya yang terjadi setelah proses algoritma genetik dilakukan akan terlihat perbedaan antara rugi-rugi daya yang terjadi sebelum dengan sesudah pemasangan kapasitor dengan algoritma genetik.

Proses algoritma genetik yang dilakukan di atas merupakan tahapan-tahapan pada kerja algoritma genetik yang terjadi pada penentuan penempatan kapasitor. Pada penelitian ini, proses di atas dilakukan oleh program algoritma genetik yang dibuat dalam pemprograman Matlab.

\section{HASIL DAN PEMBAHASAN}

Data yang dibutuhkan untuk menghitung aliran daya dengan metode Newton-Raphson adalah tegangan yang terjadi pada saluran, sudut tegangan, resistansi, reaktansi, tipe bus, besarnya daya pembangkitan, dan besarnya beban yang terjadi. Data sistem tenaga listrik interkoneksi Sumbar yang digunakan seperti Tabel 1.

Berdasarkan data-data sistem tersebut, dilakukan perhitungan aliran daya pada kondisi normal atau kondisi sebelum dilakukan penambahan kapasitor. Dari perolehan tersebut 
akan terlihat bagaimana kondisi saluran pada interkoneksi sistem sekaligus berapa rugi-rugi daya yang ditimbulkan oleh saluran tersebut. Dari hasil aliran daya ini, ada beberapa bus yang memiliki nilai tegangan diatas batas yang diijinkan PLN, batas yang diijinkan tersebut berada pada range $0.95 \leq V_{i} \leq 1.05$. Maka tegangan ini akan di perbaiki dengan penempatan kapasitor. Sedangkan nilai rugirugi daya yang diperoleh yaitu, rugi-rugi daya aktif sebesar 13.592 MW dan rugi-rugi daya reaktif sebesar 49.217 Mvar. Hasil rugi-rugi daya inilah yang akan dibandingkan dengan hasil rugi-rugi daya yang diperoleh dengan menggunakan metode algoritma genetik yang sudah mengalami penambahan kapasitor pada saluran-saluran yang sudah ditentukan.

Tabel 2. Data Pembangkitan dan Beban

\begin{tabular}{|c|c|c|c|c|c|c|c|c|}
\hline \multirow{2}{*}{ No } & \multirow{2}{*}{ Nama } & \multicolumn{2}{|c|}{ Pembangkitan } & \multicolumn{2}{|c|}{ Beban } & \multirow{2}{*}{ Tegangan } & \multirow{2}{*}{ Sudut } & \multirow{2}{*}{ Jenis } \\
\hline & & $P$ & $Q$ & $p$ & $Q$ & & & \\
\hline 1 & $\begin{array}{c}\text { PLTU } \\
\text { Ombilin }\end{array}$ & 150.0 & 68.0 & 0.0 & 0.0 & 1.05 & 0.0 & slack \\
\hline 2 & $\begin{array}{c}\text { PLTA } \\
\text { singkarak }\end{array}$ & 165.3 & 15.7 & 0.0 & 0.0 & 1.03 & 0.0 & PV \\
\hline 3 & $\begin{array}{l}\text { PLTD Sewa } \\
\text { Pauh Limo }\end{array}$ & 29.3 & 2.0 & 0.0 & 0.0 & 1.03 & 0.0 & PV \\
\hline 4 & $\begin{array}{l}\text { PLTD Sewa } \\
\text { PIP }\end{array}$ & 49.2 & 9.5 & 0.0 & 0.0 & 1.03 & 0.0 & PV \\
\hline 5 & $\begin{array}{c}\text { PLTA } \\
\text { Maninjau }\end{array}$ & 60.4 & 17.3 & 0.0 & 0.0 & 1.03 & 0.0 & PV \\
\hline 6 & $\begin{array}{l}\text { PLTU Teluk } \\
\text { Sirih }\end{array}$ & 180.0 & 70.0 & 0.0 & 0.0 & 1.03 & 0.0 & PV \\
\hline 7 & $\begin{array}{c}\text { PLTA Batang } \\
\text { Agam }\end{array}$ & 10.5 & 3.0 & 0.0 & 0.0 & 1.03 & 0.0 & PV \\
\hline 8 & Kiliran Jao & 0.0 & 0.0 & 16.6 & 3.5 & 1.00 & 0.0 & $P Q$ \\
\hline 9 & Salak & 0.0 & 0.0 & 15.3 & 4.4 & 1.00 & 0.0 & $P Q$ \\
\hline 10 & Solok & 0.0 & 0.0 & 27.7 & 6.8 & 1.00 & 0.0 & $P Q$ \\
\hline 11 & Indarung & 0.0 & 0.0 & 70.0 & 36.0 & 1.00 & 0.0 & $P Q$ \\
\hline 12 & $\begin{array}{c}\text { Simpang } \\
\text { Haru }\end{array}$ & 0.0 & 0.0 & 54.1 & 19.9 & 1.00 & 0.0 & $P Q$ \\
\hline 13 & Lubuk Alung & 0.0 & 0.0 & 25.0 & 9.6 & 1.00 & 0.0 & $P Q$ \\
\hline 14 & $\begin{array}{l}\text { Padang } \\
\text { Panjang }\end{array}$ & 0.0 & 0.0 & 16.4 & 4.6 & 1.00 & 0.0 & $P Q$ \\
\hline 15 & Padang Luar & 0.0 & 0.0 & 36.5 & 6.7 & 1.00 & 0.0 & $P Q$ \\
\hline 16 & Payakumbuh & 0.0 & 0.0 & 20.4 & 15.0 & 1.00 & 0.0 & $P Q$ \\
\hline 17 & Batusangkar & 0.0 & 0.0 & 15.0 & 2.5 & 1.00 & 0.0 & $P Q$ \\
\hline 18 & Bungus. & 0.0 & 0.0 & 23.4 & 10.4 & 1.00 & 0.0 & $P Q$ \\
\hline 19 & Pariaman & 0.0 & 0.0 & 16.5 & 3.2 & 1.00 & 0.0 & $P Q$ \\
\hline 20 & $\begin{array}{c}\text { Simpang } \\
\text { Empat }\end{array}$ & 0.0 & 0.0 & 27.7 & 6.0 & 1.00 & 0.0 & $P Q$ \\
\hline
\end{tabular}

Berdasarkan data-data sistem, dilakukan perhitungan rugi-rugi daya pada kondisi normal. Dari hasil aliran daya ini, ada beberapa bus yang memiliki nilai tegangan diatas batas yang diijinkan PLN, batas yang diijinkan tersebut berada pada range $0.95 \leq V_{i} \leq 1.05$. Hasil tersebut akan diperbaiki dengan penempatan kapasitor.
Tabel 3. Data Saluran Transmisi Interkoneksi Sumbar Riau

\begin{tabular}{|c|c|c|c|}
\hline \multicolumn{2}{|c|}{ Line } & \multicolumn{2}{c|}{$\mathbf{Z}$ (pu) } \\
\hline Dari Bus & Ke Bus & $\mathbf{R}$ & $\mathbf{X}$ \\
\hline 1 & 8 & 0.015835 & 0.093600 \\
\hline 1 & 9 & 0.001249 & 0.004164 \\
\hline 2 & 13 & 0.004571 & 0.018901 \\
\hline 2 & 14 & 0.013687 & 0.045619 \\
\hline 3 & 12 & 0.003688 & 0.012292 \\
\hline 3 & 13 & 0.018433 & 0.061441 \\
\hline 3 & 11 & 0.002674 & 0.011059 \\
\hline 4 & 13 & 0.013578 & 0.045257 \\
\hline 5 & 15 & 0.022833 & 0.076105 \\
\hline 6 & 18 & 0.001684 & 0.005612 \\
\hline 7 & 16 & 0.030833 & 0.10277 \\
\hline 9 & 10 & 0.015180 & 0.050598 \\
\hline 10 & 11 & 0.018520 & 0.061731 \\
\hline 13 & 5 & 0.030833 & 0.10277 \\
\hline 14 & 17 & 0.006789 & 0.022629 \\
\hline 15 & 16 & 0.017461 & 0.058201 \\
\hline 16 & 17 & 0.004226 & 0.034782 \\
\hline 18 & 11 & 0.006789 & 0.022629 \\
\hline 19 & 5 & 0.023267 & 0.077553 \\
\hline 19 & 13 & 0.007642 & 0.025471 \\
\hline 20 & 5 & 0.041070 & 0.136894 \\
\hline
\end{tabular}

Sedangkan nilai rugi-rugi daya yang diperoleh yaitu, rugi-rugi daya aktif sebesar 13.592 MW dan rugi-rugi daya reaktif sebesar 49.217 Mvar. Hasil rugi-rugi daya inilah yang akan dibandingkan dengan hasil diperoleh dengan menggunakan metode algoritma genetik yang sudah mengalami penambahan kapasitor pada saluran - saluran yang sudah ditentukan.

Penggunaan metoda algoritma genetik pada penentuan pemasangan kapasitor berdasarkan pada beberapa parameter, yaitu $p_{\text {cross }}$ dan $p_{\text {mut }}$. Nilai $p_{\text {cross }}$ dan $p_{\text {mut }}$ yang terjadi akan berbengaruh pada nilai sebaran yang diperoleh.

Tabel 4.3 Nilai pcross dan pmutasi

\begin{tabular}{|c|c|}
\hline pcross & P mut \\
\hline 0.7 & 0.02 \\
\hline 0.8 & 0.035 \\
\hline 0.9 & 0.05 \\
\hline 1 & 0.5 \\
\hline
\end{tabular}

Penggunaan nilai pmut dan pcross yang digunakan sebagai percobaan dalam penelitian ini yaitu:

1. Percobaan 1 dengan $p_{\text {cross }} 0.7$ dan $p_{\text {mut }} 0.02$

2. Percobaan 2 dengan $p_{\text {cross }} 0.7$ dan $p_{\text {mut }} 0.035$

3. Percobaan 3 dengan $p_{\text {cross }} 0.7$ dan $p_{\text {mut }} 0.5$

4. Percobaan 4 dengan $p_{\text {cross }} 0.8$ dan $p_{\text {mut }} 0.035$ 
5. Percobaan 5 dengan $p_{\text {cross }} 0.8$ dan $p_{\text {mut }} 0.05$

6. Percobaan 6 dengan $p_{\text {cross }} 0.8$ dan $p_{\text {mut }} 0.5$

7. Percobaan 7 dengan $p_{\text {cross }} 0.9$ dan $p_{\text {mut }} 0.02$

8. Percobaan 8 dengan $\mathrm{p}_{\text {cross }} 0.9$ dan $\mathrm{p}_{\mathrm{mut}} 0.05$

9. Percobaan 9 dengan $p_{\text {cross }} 0.9$ dan $p_{\text {mut }} 0.5$

10. Percobaan 10 dengan $p_{\text {cross }} 1$ dan $p_{\text {mut }} 0.035$

11. Percobaan 11 dengan $p_{\text {cross }} 1$ dan $p_{\text {mut }} 0.05$

12. Percobaan 12 dengan $p_{\text {cross }} 1$ dan $p_{\text {mut }}$ t 0.5

Parameter-parameter lain yang digunakan bernilai sebagai berikut:

- Max iterasi bernilai 13

- Jumlah gen (jumlah bus) sebanyak 20

- Jumlah kromosom sebanyak 20

Dari percobaan yang dilakukan dengan melakukan variasi nilai parameter di atas, akan diambil nilai rugi-rugi daya yang terkecil dari tiap percobaan.

Tabel 4. Rugi-Rugi Saluran Setelah Menggunakan Metode Algoritma Genetik

\begin{tabular}{|c|c|c|c|}
\hline \multirow{2}{*}{ Percobaan } & \multirow{2}{*}{ Kromosom } & \multicolumn{2}{|c|}{ Rugi-rugi yang terjadi } \\
\cline { 3 - 4 } & & MW & Mvar \\
\hline 1 & 2 & 16.864 & 59.845 \\
\hline 2 & 8 & 17.011 & 60.002 \\
\hline 3 & 18 & 17.256 & 65.592 \\
\hline 4 & 7 & 16.376 & 63.030 \\
\hline 5 & 18 & 13.920 & 51.716 \\
\hline 6 & 9 & 14.187 & 61.681 \\
\hline 7 & 15 & 15.066 & 62.682 \\
\hline 8 & 8 & 18.516 & 62.002 \\
\hline 9 & 6 & 17.427 & 60.437 \\
\hline 10 & 5 & 17.580 & 60.123 \\
\hline 11 & 14 & 6.244 & 26.814 \\
\hline 12 & 2 & 15.529 & 31.606 \\
\hline
\end{tabular}

Berdasarkan Tabel 4 dilakukan pemilihan nilai rugi-rugi daya terkecil. Nilai rugi - rugi daya terkecil terdapat pada percobaan 11. Jadi berdasarkan percobaan yang dilakukan, percobaan 11 yang akan menjadi acuan penempatan kapasitor untuk memperbaiki tegangan dan mengurangi rugi-rugi daya. Hasil pada percobaan ke-11 menunjukkan pada kromosom ke-14 yang memiliki nilai dengan rugi-rugi terkecil sesuai dengan kondisi di atas. Dari hasil aliran daya yang diperoleh, hal pertama yang diperhatikan adalah profil tegangan yang terjadi. Dari hasil aliran daya dengan menggunakan metode algoritma genetika diatas terlihat nilai tegangan turun. Nilai tegangan setelah menggunakan algoritma genetika berada pada range yang diijinkan, sehingga profil tegangan baik bagi sistem. Grafik berikut ini adalah perbandingan nilai tegangan pada jaringan transmisi di Sumatera Barat sebelum penempatan kapasitor dan sesudah penempatan kapasitor.

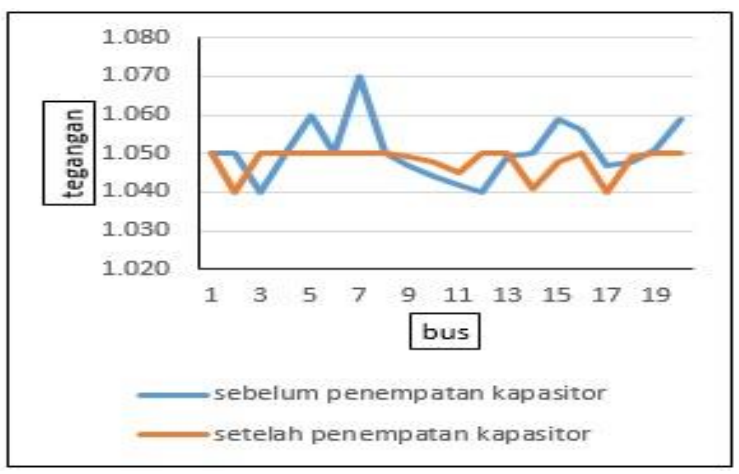

Gambar 3. Grafik profil tegangan sebelum dan sesudah penempatan kapasitor

Berdasarkan hasil aliran daya setelah penempatan kapasitor dengan algoritma genetika, maka kapasitor dipasang pada 8 tempat, yaitu pada bus $1,3,5,7,13,16,17$ dan 20. Nilai kapasitor pada bus 1 sebesar 220 Mvar, bus 3 sebesar 270 Mvar, bus 5 sebesar 360 Mvar, bus 7 sebesar 20 Mvar, bus 13 sebesar 290 Mvar, bus 16 sebesar 290 Mvar, bus 17 sebesar 350 dan bus 20 sebesar 230 Mvar. Karena sistem yang digunakan adalah sistem interkoneksi, maka pemasangan kapasitor yang dilakukan tidak harus berada pada bus atau saluran yang mengalami kondisi profil tegangan buruk, namun bisa dipasang di saluran lain yang memiliki hubungan pada saluran yang mengalami profil tegangan yang buruk tersebut.

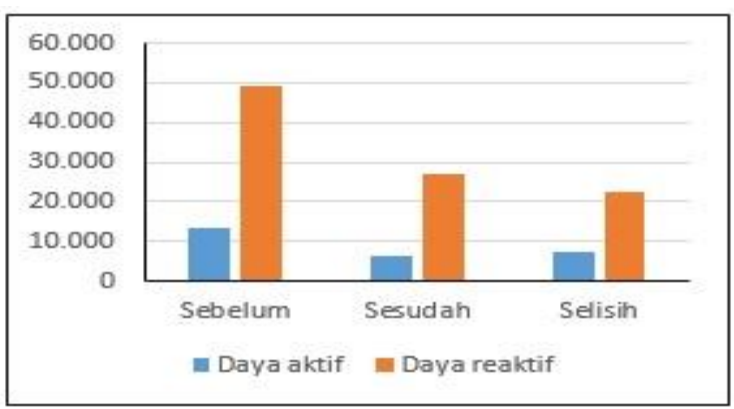

Gambar 4. Grafik perbandingan rugi-rugi saluran sebelum dan sesudah penambahan kapasitor dengan algoritma genetika. 


\section{KESIMPULAN}

1. Rugi - rugi daya yang terjadi pada sistem interkoneksi Sumbar sebesar 13.592 MW untuk daya aktif dan 49.217 Mvar untuk daya reaktif.

2. Kapasitor ditempatkan pada bus 1, 3, 5, 7, 8, 16, 17 dan 20. Nilai kapasitor pada bus 1 sebesar 220 Mvar, bus 3 sebesar 270 Mvar, bus 5 sebesar 360 Mvar, bus 7 sebesar 20 Mvar, bus 8 sebesar 290 Mvar, bus 16 sebesar 290 Mvar, bus 17 sebesar 350 dan bus 20 sebesar 230 Mvar.

3. Hasil rugi-rugi daya yang diperoleh setelah pemasangan kapasitor dengan metode algoritma genetik adalah sebesar 6.244 MW untuk daya aktif dan 26.814 Mvar untuk daya reaktif. Jadi metode algoritma genetik telah mengurangi rugi-rugi daya pada saluran interkoneksi Sumbar sebesar 7.348 MW untuk daya aktif dan 22.403 Mvar untuk daya reaktif.

\section{DAFTAR PUSTAKA}

[1] http://stlftui.wordpress.com,_diakses 29 Oktober 2014.

[2] http://ghojer.blogspot.com,_ diakses 26 Desember 2014.

[3] Brown, L. A., Williams, A. \& Rogers, B., Title of paper, Name of Journal 8, 20-25 (1999).

[4] Brown, L. A., Williams, A. \& Rogers, B., Title of book, ed. 2, Publisher (1997).

[5] Alamajibuwono, Hadha. 2011. "Optimasi Penempatan Kapasitor Menggunakan Algorima Genetika pada Sistem Distribusi untuk Memperbaiki Faktor Daya dan Tegangan”. (Tugas Akhir) Semarang: Jurusan Teknik Elektro Fakultas Teknik Universitas Diponegoro.

[6] Suyanto, 2005, Algoritma Genetik dalam MATLAB, ANDI, Yogyakarta

[7] Laksono, Heru Dibyo dan Reri Afrianita. 2007. "Studi Aliran Daya Dengan Metode Newton Raphson"dalam jurnal Teknik Elektro Unand Padang: Jurusan Teknik Elektro Unand.

[8] Wartana, I Made dan Mimien Mustikawati. 2006. Optimasi Penempatan Kapasitor pada Saluran Distribusi 20 kV dengan Menggunakan Metode Kombinasi Fuzzy dan Algoritma Genetika. Seminar
Nasional Aplikasi Teknologi Informasi. Yogyakarta.

\section{Ucapan Terima Kasih}

Saya ucapkan terima kasih kepada Jurusan Teknik elektro Universitas Andalas Fakultas Teknik, yang sudah memberikan dukungan dan bantuan finasial, sehingga saya dapat melakukan penelitian ini. Saya juga ingin menyampaikan banyak terima kasih kepada perusahaan PLN yang telah mendukung penyediaan informasi tentang data grid di wilayah Sumatera Barat.

Dan tidak lupa terima kasih pada rekan-rekan saya atas dukungan dan dorongan mereka sepanjang penelitian saya.

\section{Biodata Penulis}

Syukri Yunus, S1 di Jurusan Teknik Elektro ITB tahun 1985 bidang Teknik tenaga Listrik, S2 di Jurusan Ilmu Komputer UI tahun 1991. Sekarang sebagai staf Pengajar di Jurusan Teknik Elektro FT Unand.

Email: syukri_yunus@ft.unand.ac.id

Heru Dibyo Laksono, S1 di Jurusan Teknik Elektro Unand tahun 2000 bidang Teknik tenaga Listrik, S2 di Jurusan Teknik Elektro ITB tahun 2004. Sekarang sebagai staf Pengajar di Jurusan Teknik Elektro FT Unand.

Putri Nidia, Lahir di Lubuk Alung, 17 Mei 1993. S1 di Jurusan Teknik Elektro Universitas Andalas (Unand). Padang tahun 2015 bidang Teknik Tenaga Listrik. 